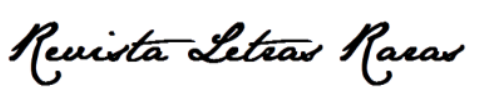

ISSN: 2317-2347 - v. 9, n. 4 (2020)

Todo o conteúdo da RLR está licenciado sob Creative Commons Atribuição 4.0 Internacional

\title{
O crime da Galeria de Cristal, de Boris Fausto: um estudo sobre
}

\author{
intermídia e sensacionalismo / \\ O crime da Galeria de Cristal, by Boris Fausto: a study about \\ intermedia and sensationalism
}

\section{Maria Salete Borba *}

Possui Bacharelado em Pintura e Gravura (2000) e Especialização em Linguagens Visuais Contemporâneas (2003) pela Universidade do Estado de Santa Catarina; Licenciatura em Letras (Português e Francês) (2003); Mestrado (2005), Doutorado (2009) e Pós-doutorado (2012) em Literatura pela Universidade Federal de Santa Catarina. Doutorado sanduíche pela Universidade de Leiden (2008).

iD https://orcid.org/0000-0002-8503-8387

\section{Taynara Leszczynski ${ }^{* *}$}

Mestranda no Programa de Pós-Graduação em Letras (PPGL), da Universidade Estadual do Centro-Oeste (UNICENTRO). Licenciatura em Letras - Português e Literaturas de Língua Portuguesa (2018), pela Universidade Estadual do Centro-Oeste (UNICENTRO) e Letras - Português e Inglês (2018) pelo Centro Universitário de Maringá (UNICESUMAR).

iD https://orcid.org/0000-0002-8219-0885

Recebido: 28 mai. 2020. Aprovado: 26 jun. 2019.

\section{Como citar este artigo:}

LESZCZYNSKI, Taynara; BORBA, Maria Salete. 0 crime da Galeria de Cristal, de Boris Fausto: um estudo sobre intermídia e sensacionalismo. Revista Letras Raras. Campina Grande, v. 9, n. 4, p. 205-226, dez. 2020.

\section{RESUMO}

O presente artigo tem por objetivo analisar o conceito de intermídia no livro O Crime da Galeria de Cristal e os dois crimes da mala: São Paulo, 1908-1928 (2019), do historiador e escritor brasileiro Boris Fausto. Pretende-se apontar e discutir as intersecções e fronteiras midiáticas entre as várias esferas que se entrelaçam na sua escrita, bem como observar o surgimento do sensacionalismo na imprensa brasileira, sobretudo, por meio de faits divers. Para dar suporte a esse estudo, nos baseamos no conceito de intermídia, de Higgins (2012), o qual pode ser visto no livro de Fausto (2019) através da presença de traços de origens múltiplas, como da literatura, jornal, rádio, cinema e teatro, que se conectam por meio do interesse grotesco e sanguinário da sociedade por crimes, principalmente, assassinatos. Embora as três histórias do livro de Fausto (2019) sejam factuais, ambas ocorridas em meados do século XX, em São Paulo, assemelham-se bastante a contos. Essa dificuldade em

** 


\section{Penista Letras Parar \\ ISSN: 2317-2347 - V. 9. n. 4 (2020) \\ Todo o conteúdo da RLR está licenciado sob Creative Commons Atribuição 4.0 Internacional}

classificar essa escrita dentro dos moldes de gêneros textuais e literários também vem a ser uma característica da intermídia. Ademais, pela presença de fragmentos tanto imagéticos quanto textuais, pode ser visto como uma escrita de almanaque, segundo Dias (2016). Tudo isso, sob uma atmosfera de suspense que remete às narrativas policiais. Nesse sentido, também nos pautamos em alguns teóricos que discorrem sobre o universo literário policialesco, como Moraes (2019), Pontes (2007), Reimão (2005), Souza (2000), Piglia (1986) e Albuquerque (1979); para refletir as relações de literatura e outras linguagens: Antelo (2000), Brait (2010), Ferreira (2006) e Longui (2020).

PALAVRAS-CHAVE: Intermídia; Sensacionalismo; Criminalidade.

\section{ABSTRACT}

This article aims to analyze the concept of intermedia in the book $O$ crime da Galeria de Cristal e os dois crimes da mala: São Paulo, 1908-1928, published in 2019, by Boris Fausto (Brazilian historian and writer). We intend to point out and to discuss the intersections and media borders between the various spheres that are connected in its writing. As well, this study also aims to observe how the sensationalism took place in Brazilian press through the fait divers. In order to support this research, we resort to the concept of intermedia, by Higgins (2012), which can be seen in Fausto's book (2019) through the presence of traces of multiple origins as literature, newspaper, radio, cinema and theater, which are connected through society's grotesque and bloodthirsty interest in crimes, mainly murders. Although the three stories in Fausto's book (2019) are factual, both occurried in the mid-twentieth century, in São Paulo, they are very similar to short stories. This difficulty in classifying this writing within the models of textual and literary genres is also a characteristic of intermedia. Furthermore, due to the presence of both images e texts fragments, it can be seen as an almanac writing, according to Dias (2016). All of this, under an atmosphere of suspense that refers to detective narratives. In this sense, we are also guided by some theorists who study about the detective literary universe, as Moraes (2019), Pontes (2007), Reimão (2005), Souza (2000), Piglia (1986) and Albuquerque (1979); in order to reflect the relations of literature and other languages: Antelo (2000), Brait (2010), Ferreira (2006) and Longui (2020).

KEYWORDS: Intermedia; Sensacionalism; Criminality.

\section{Introdução}

Em O crime da Galeria de Cristal: e os dois crimes da mala: São Paulo 1908-1928, publicado em 2019, pela editora Companhia das Letras, Boris Fausto faz um trabalho de pesquisa bastante aprofundado, a fim de (re)escrever detalhadamente três crimes ocorridos na capital paulista e que abalaram o país no início do século XX.

De acordo com a ficha catalográfica do livro, ele faria parte da seção "Crimes - História". Contudo, há algo de inusitado em sua construção, que faz com que tal classificação seja problemática, pois é bastante difícil identificar a qual gênero esse livro pertence, ainda mais se o leitor for desavisado e não tiver conhecimento da real ocorrência dos crimes selecionados.

Dessa maneira, o livro poderia ser visto tanto como um material historiográfico, como é proposto, quanto ficção, pelo viés da literatura policial, bem como devido ao seu formato semelhante ao de contos. Ou ainda, ser lido como um texto de cunho jornalístico-investigativo, tendo em vista os recortes de páginas de jornais das seções criminalísticas presentes nele.

Em síntese, isso ocorre porque o autor se apoia em diversas mídias na sua escrita. Em seu livro podemos encontrar diversos fragmentos textuais e imagéticos, dispostos de maneira anacrônica, por meio de um procedimento parecido com o da colagem, das artes. Tais elementos vão desde documentos 


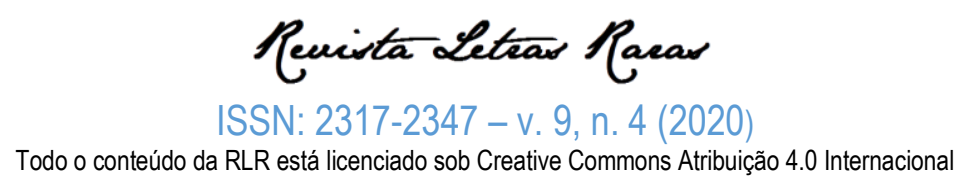

e fotografias históricas, a charges, ilustrações, piadas, depoimentos de testemunhas, notícias, comentários da população, trechos de folhetins etc.

Logo na parte inicial da sinopse do livro, que pode ser encontrada na contracapa, tem-se um texto que relembra significativamente às sinopses de contos ou romances policiais: "um homem é assassinado num quarto de hotel no centro da cidade. Um cadáver é encontrado numa mala quando um passageiro do navio tentava jogá-la ao mar. Um corpo de uma mulher é descoberto ao içarem as bagagens de uma embarcação" (FAUSTO, 2019, c. c.).

Por outro lado, a partir da leitura do livro, vemos que além da presença dos crimes reais e dos trechos de jornais, também há várias referências a pessoas que de fato existiram e foram importantes no cenário da criminologia, tanto em relação aos casos selecionados, como os nomes dos promotores, juízes e advogados que trabalhavam no entorno do acontecimento, quanto a nomes relevantes à criminalidade de forma geral, como Cesare Lombroso e seu método questionável de "identificar 0 criminoso" pelas características físicas (FAUSTO, 2019, p. 107).

Vê-se, portanto, que 0 autor transita na fronteira entre ficção e fato. Apesar de ele estar mais vinculado à necessidade de trazer os fatos como realmente aconteceram, com imparcialidade, principalmente, pela sua formação enquanto historiador, ele também é afetado pela ficção pela própria condição de colocar esses crimes em um livro e também pela camada de suspense onírico que está sempre presente na criminologia. Nesse sentido, Tony Bellotto ${ }^{1}$ apud Fausto (2019), destaca que:

O crime da Galeria de Cristal tem o rigor acadêmico digno do historiador, mas embebido de uma atmosfera noir que lembra Georges Simenon e Edgar Allan Poe. É a exposição objetiva (ora distanciada, ora irônica, sempre brilhante) de incríveis e inexplicáveis paixões, que preferimos esconder na mala (BELLOTTO, apud FAUSTO, 2019, [orelha do livro]).

Assim, o livro é um apelo à imaginação, mas ao mesmo tempo, um convite à intertextualidade e à intermidialidade. Um produto cultural que é reflexo não só da fragmentação da sociedade, tão presente na modernidade, como também do excesso de informações e conteúdos, das mais diversas áreas que chegam às pessoas nos dias de hoje, tornando quase que impossível uma escrita que não esteja perpassada por diferentes mídias e diferentes gêneros.

Nos três casos trazidos pelo autor há certa recorrência das características dos personagens. Todos representam as ruínas da sociedade moderna; aquilo que há de podre na humanidade. A violência, a crueldade, o medo e a morte. São ecos da modernidade retomados a fim de demonstrar a parte da

\footnotetext{
1 Popularmente conhecimento como guitarrista da banda brasileira Titãs, mas é também escritor, com ênfase no diálogo entre literatura policial e terror.
} 


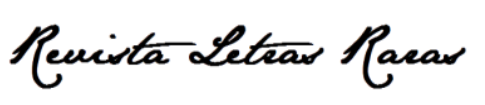

ISSN: 2317-2347 - v. 9. n. 4 (2020)

Todo o conteúdo da RLR está licenciado sob Creative Commons Atribuição 4.0 Internacional

história que não é contada; os anti-heróis marginais que são apagados; personagens miseráveis que vivem e que matam por pouco, no silêncio, no escuro, no vazio. Seres sociais abjetos que nos são apresentados por um narrador transeunte na linha da promessa de verdade da história e da construção enigmática do universo imaginativo literário.

Boris Fausto é um historiador, cientista político, escritor e professor aposentado do Departamento de Ciência Política da Universidade de São Paulo (USP). Nascido em 1930, na capital São Paulo, onde ainda reside, também é autor de 0 crime do restaurante chinês: carnaval, futebol e justiça na São Paulo dos anos 30 (2009), Negócios e ócios: histórias da migração (1999) e A revolução de 1930: historiografia e história (1970). Sempre mostrando forte interesse por trabalhar a criminalidade. Em O crime da galeria de cristal (2019), o seu trabalho mais recente, podemos claramente identificar uma construção intermidiática.

Mas afinal, o que é intermídia? Esse é um conceito criado pelo compositor, poeta e músico britânico Dick Higgins e trata-se de certa coexistência simultânea de mídias diferentes na mesma obra. O que forma, portanto, uma composição híbrida. Além da sua relevância no âmbito da música e das artes, o multiartista também teve uma contribuição significativa à teoria da literatura moderna, sobretudo, no que condiz à poesia concreta que, posteriormente, seria uma referência às discussões atuais sobre a interpoesia.

De acordo com Ferreira (2006), Higgins foi protagonista do grupo Fluxus, um movimento artístico que teve ênfase nas décadas de 1960 e 1970, com um intuito de propor inovações no campo artístico por meio de ideias libertárias. Nesse espaço, Higgins estudava e trabalhava diversos temas, como happenings, intermídia, poesia, cinema, música etc.

O conceito de intermídia, apesar de ter surgido há bastante tempo, teve uma difusão um tanto quanto lenta, alcançando mais visibilidade da virada do século XX para o XXI até os dias de hoje, os quais têm sido o seu palco central. Um conceito próximo da intertextualidade, já muito conhecida, mas que se diferencia dela por abranger, além de diferentes textualidades, diferentes mídias que as produzem.

Isso pode ser visto no livro de Fausto (2019) por meio da fusão das mídias: jornal, a partir dos recortes que apresenta; música, com as "modinhas", feitas acerca dos crimes, que eram tocadas e cantadas pelo povo, como o autor sublinha "[...] os casos pioneiros - em particular, o primeiro - foram cantados em prosa e verso [...]" (FAUSTO, 2019, p. 206); literatura, devido ao formato similar ao conto, bem como à camada de suspense e investigação, comum ao universo literário policial; fotografia, uma vez que há várias presentes no livro e que funcionam como arquivo; arte, por meio das ilustrações; cinema e teatro, através das adaptações e peças produzidas com base nos casos, pelas menções à alta 


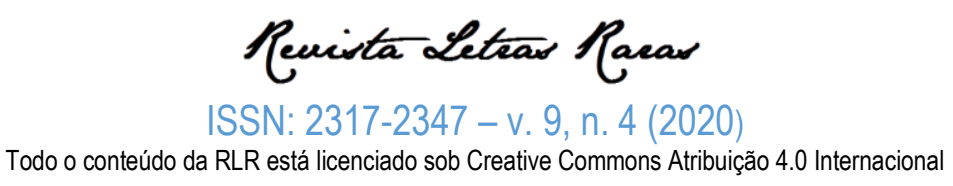

frequência da população a esses espaços para assistir a tais produções, bem como críticas e comentários acerca do conteúdo lá apresentado.

A intermídia, hoje vista com mais frequência na literatura, alcançou maior espaço nela por meio das poesias concretas, que traziam em si diálogos com exterioridades, como é o caso do poema "Lixo Luxo", de Augusto de Campos, enquanto uma crítica à sociedade de consumo e ao capitalismo. Também pode-se lembrar do "Poema tirado de uma notícia de jornal", de Manuel Bandeira, no qual o poeta, a partir de uma notícia de jornal, faz um recorte e muda a disposição dos elementos da notícia transformando-a em de poema.

Tal gesto de Bandeira pode ser visto de diferentes perspectivas, se considerarmos o contexto de produção, um ready-made assistido, uma vez que o objeto é retirado de seu local originário e sua função corriqueira (jornal/informar) e é reconfigurado a poema. E ao mesmo tempo uma composição intermidiática, já que a obra final é perpassada pela literatura e pelo jornalismo. 0 ato de levar o jornal para o livro e, na atualidade, de levar o livro físico para os e-readers digitais também pode ser visto como um gesto intermidiático pela mesma razão. Com isso, entende-se que a intermídia trata desse ponto de enlace entre duas ou mais mídias. 0 elo de conexão entre elas.

Dessarte, a intermidialidade tem diferentes formas, áreas, enfim, possibilidades de se manifestar. Outras que podem ser citadas são o Happening, do campo das artes visuais, que apresenta elementos e semelhanças às artes cênicas. De acordo com Longui (2002) "O que chamou a atenção de Higgins para desenvolver a Intermedia foi 0 advento do happening, no final dos anos 50 e começo dos 60 " (LONGUI, 2002, p. 2). Consequentemente:

O Happening tem origem na idéia de "colagem": em meados da década de 50, pintores nos Estados Unidos e na Alemanha começaram a voltar-se para trabalhos em que criavam adicionando ou removendo, substituindo ou alterando componentes da obra visual. Começaram incluindo objetos em suas obras, em seguida realizando colagens que envolviam o espectador, e classificaram-nas como "ambientes" (LONGUI, 2002, p. 3).

Em tempos tão inigualáveis, conturbados e, acima de tudo, digitais, como os de hoje, é inevitável pensar na morte do livro físico, de sua falência, de seu desuso. A literatura impressa vem se tornando escassa há tempo, devido aos avanços tecnológicos que trouxeram consigo novos suportes de leitura que podem ser feitos pelos computadores e celulares, sem a necessidade da impressão, permitindo pesquisas e escritas mais rápidas e com baixo custo financeiro. Se por um lado, cada vez menos se fala das características de livros físicos, como tipos de folhas, capas, pesos e encadernações, do outro, cada vez mais se comenta acerca de novos formatos de e-books, como mobi, pdf, epub, azw, iba etc. 


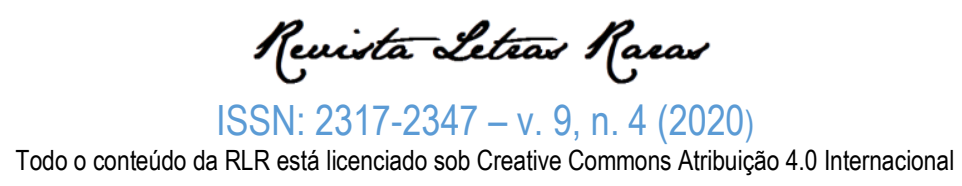

Com a literatura, bem como outras artes e formas de manifestações da linguagem, imigrando para o âmbito digital, torna-se quase que inevitável as conexões entre elas. Suas fronteiras vão se tornando opacas e suas intersecções nítidas. Assim, (re) pensar a intermídia para os dias atuais é imprescindível. Deve-se considerar as novas tecnologias como influências decisivas nesse processo multifacetado, bem como o caos contemporâneo que reflete em uma tessitura narrativa fragmentada.

Portanto, Higgins (2012) obteve muito sucesso em sua afirmação de que o futuro da arte é a mídia. $O$ autor ainda tomou exemplo a ascensão da obra de Duchamp, pautada na mídia, em contraste com o apagamento da de Picasso.

O ready-made ou objet trouvé, de certo modo uma intermídia, uma vez que não tem a intenção de se conformar à pura mídia, geralmente sugere isto, e, portanto sugere uma locação no campo entre a área geral da mídia arte e aquela da mídia vida (HIGGINS, 2012, p. 43).

Entendido o ready-made como uma intermídia, como proposto por Higgins (2012), nota-se que não se trata mais de pensar se a mídia entra na arte. Ela já entrou. Nesse sentido, para o autor, é indispensável destacar o papel da colagem no princípio disso, mas demonstrando que a intermídia vai além. Assim, o poeta cita exemplo de pintores que começaram a incluir cada vez mais objetos incongruentes em suas obras, nomeando tal fazer artístico de "combinações". O que começou com uma ideia de inovar em detalhes, tornou-se totalmente diferente.

Para Higgins (2012), a arte atual precisa de mais "[...] portabilidade e flexibilidade, e isto o teatro tradicional não pode dar" (HIGGINS, 2012, p. 45)". Muito embora não haja um compromisso da arte em seguir as transformações da sociedade, é incabível pensar em uma arte que as ignora. Assim, a maneira pela qual a sociedade atualiza seus pontos de vista também influencia na forma que ela se relaciona, produz e consome arte.

O autor ainda explica que é difícil categorizar a colagem ou tentar impor regras e leis a ela, no sentido de pensar uma estrutura ou uma sequência de passos a serem seguidos para fazê-la, pois "[...] cada obra determinar seu próprio meio e forma de acordo com suas necessidades" (HIGGINS, 2012, p. 45). A exemplo disso, o poeta menciona alguns artistas que misturaram a intermídia entre música à filosofia, música à escultura, poesia e escultura etc. Por fim, ele conclui que, dessa forma, a intermídia é uma histórica e irreversível inovação.

Em O crime da Galeria de Cristal (2019), por sua vez, vemos uma intermídia determinada pela intersecção entre texto e imagem e por subdivisões em cada uma delas. A título de exemplo, o livro apresenta passagens das cinco sequências textuais base: narrativa, no momento em que narra os casos, a partir da voz de um narrador onisciente neutro; argumentativa, quando baseia-se em documentos 


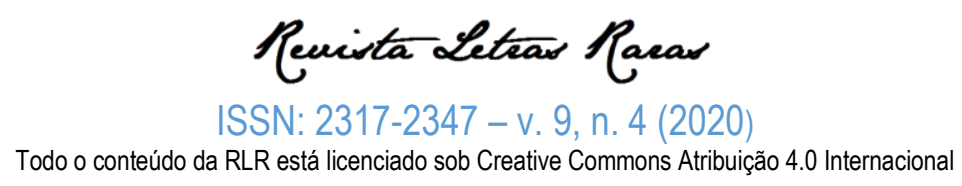

históricos, leis ou nomes de autoridade para discorrer acerca de algum elemento dos episódios; descritiva, principalmente, ao descrever com precisão ao leitor o espaço dos acontecimentos e as características dos personagens; explicativa, pelo ato de selecionar e apresentar informações que o leitor precisa saber para construir o seu entendimento, bem como por se caracterizar de certa forma uma historiografia; e ainda, conversacional ao inserir diálogos dos personagens ou reconstituições de como poderiam ter sido.

Nos recursos imagéticos: ilustrações e fotografias antigas dos lugares mais importantes, tanto culturalmente quanto no que condiz à modernização para esse período, tais como as sedes dos jornais de maior renome, o Teatro Colombo, Cine Bijou Theatre, a Estação Norte (de trens), o Bonde de Bom Retiro e, juntamente a isso, os locais de interesse à investigação dos crimes, como casas e pensões onde as vítimas e suspeitos haviam morado, espaços onde os delitos ocorreram, lugares públicos próximos, entre outros.

O capítulo 11, intitulado "Os crimes em letra e imagem" (FAUSTO, 2019, p. 206), ilustra muito bem tal afirmação. Nele, o autor evidencia que além das notícias sobre os crimes, o que é bastante comum, algo de diferente ocorreu, pois, a partir deles, diversas produções foram feitas "[...] em livros, em fascículos publicados nos jornais, em romances e filmes" (FAUSTO, 2019, p. 206). Segundo o historiador, a popularidade dos casos de criminalidade era tão sensacional e ficcionalizada que cerca de vinte salas de cinema tiveram de ser instaladas no Rio de Janeiro para que a população pudesse assistir ao filme sobre o crime da mala.

Nota-se que os crimes sensacionais são perpassados por mídias, sendo apresentados à moda e estilo particular de cada uma. Outro exemplo disso, vem do contexto teatral. "O mais notável do gênero, no entanto, é o do teatrólogo Artur Azevedo (1855-1908), ao explorar o suposto medo dos homens de serem vítimas de Michel Trad [...]" (FAUSTO, 2019, p. 208). E, a seguir, o autor insere no livro o roteiro da peça, do qual, destaca-se o trecho final abaixo:

D. Felisberta: - Pois bem! Um bonito rapaz chegou-se tanto, tanto, para mim que eu the perguntei:

- Que quer o senhor? - Sabe você o que elle me respondeu? - Quero amá-la!

Trancoso (dando um pulo da cama) - A mala? Quem foi esse patife? Vou amanhã à polícia! Quer meter-me também dentro da mala!... (FAUSTO, 2019, p. 209).

$\mathrm{Na}$ literatura, por meio da narrativa, e no cinema, por meio do filme, o crime assemelhou-se ao gênero de suspense e investigação. No entanto, observa-se nessa peça teatral um tom humorístico. Um assunto sério: a morte, se desdobra da tragédia à comédia. Entra no folclore nacional, no imaginário social acerca de vilões e heróis. Vê-se, assim, que o crime sensacional, isto é, aquele que desperta uma forte comoção na população, devido à alta divulgação e enfatização que a imprensa constrói em torno 


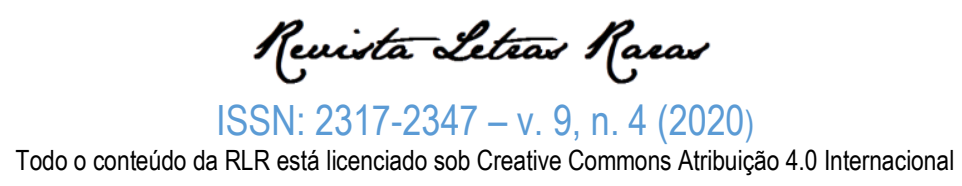

dele, tem a possibilidade de adentrar diferentes espaços e se reconfigurar em cada um deles. Fausto (2019), ao demonstrar como cada crime é retratado em cada mídia, apresenta muito bem esse fato.

\section{Crimes que contam histórias}

Em entrevista ao jornal Folha de São Paulo (2019), para a produção de um podcast, Boris Fausto sublinha que o seu interesse acerca desses assassinatos relatados no livro se deve ao fato de que "Crimes revelam muito sobre a história"2. Assim, sob o seu olhar de historiador, logo no início de seu livro, faz uma explicação e certo auto questionamento acerca do porquê de ter escolhido esses três crimes para escrever sobre, muito embora a literatura não necessite de razões ou finalidades. Nesse contexto, ele dá ênfase a cinco aspectos, os quais em seu ponto de vista, serviram de fundo na constituição da São Paulo de hoje.

Por que escolhi a trinca, em meio a tantos e tantos outros casos? Em primeiro lugar, levando em conta as possibilidades narrativas de todos eles. Depois, pelo papel relevante desempenhado pelas mulheres, em situações diversas, em cada um dos casos; pela possibilidade de considerar a instituição do júri sob um ângulo particular; pelo tema do papel da imprensa, ao mesmo tempo como formadora e reflexo da opinião pública; pelo assunto da inserção das etnias estrangeiras na sociedade paulistana (FAUSTO, 2019, p. 12).

O historiador faz uma completa introdução dos principais jornais paulistanos, sendo eles, 0 Estadão, o Correio Paulistano e o Commercio de São Paulo, suas visões e o seus impactos sociais. Em geral, eles tinham como temas mais recorrentes questões de cunho político e de criminalidade. E, para Fausto (2019) é a partir desses jornais que o sensacionalismo no Brasil surge.

Segundo o autor, o sensacionalismo na imprensa brasileira teria sido criado e desenvolvido, mais precisamente, na época em que os três crimes do livro aconteceram. Nesse sentido, para ele, o sensacionalismo se constrói em território nacional, em cima da criminalidade. No conto "O crime da Galeria de Cristal", há o subtítulo "A Galeria de Cristal. O crime-folhetim" (FAUSTO, 2019, p. 41). Podese considerar que o crime folhetim seria o crime sensacional. Um caso diferente dos corriqueiros e que se destaca por meio do inusitado.

Não obstante, o também historiador, José Geraldo Vinci de Moraes (2019) traz uma reflexão bastante interessante, mostrando como os crimes modificaram a imprensa da época, formando um novo

\footnotetext{
${ }_{2}$ Manchete da Folha de São Paulo, referente a entrevista concedida por Boris Fausto no dia 08 de abril de 2019. Disponível em: https://www1.folha.uol.com.br/ilustrissima/2019/04/crimes-revelam-muito-sobre-a-historia-diz-boris- fausto.shtml
} 


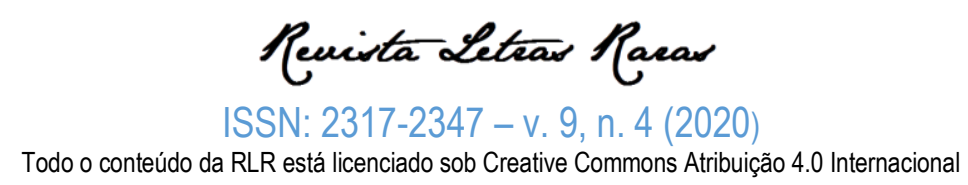

panorama cultural. 0 autor enfatiza a importância que certos comércios populares da época tiveram, como é o caso do Café Guarany, também citado por Boris Fausto, como espaços centrais na difusão de informações e na visibilidade dos crimes.

É surpreendente como a partir desses pequenos indícios que despontavam na imprensa é possível reunir vestígios da formação do moderno circuito de práticas e difusão musicais que se ajustava às profundas mudanças que ocorriam na cidade (MORAES, 2019, p. 172).

Os crimes servem de pontos para situar a mudança que a sociedade paulistana sofria. E ainda, para impulsioná-la, tendo forte participação no advento da expansão de espaços culturais como cinema, museus e teatro. Tal como já apontado, devido à instalação de várias salas de cinema para os filmes sobre os crimes serem transmitidos. O crime também moldou uma parte significativa da história e da formação do jornalismo brasileiro. Ele proporcionou uma ampliação no formato do jornal, na classificação das notícias e da especialização de cada jornalista.

Com o tempo, foi necessário até mesmo estabelecer a diferenciação de assuntos e colunas, criando uma espécie de divisão interna, aparecendo assim as colunas especiais destinadas aos crimes, à vida boêmia, ao entretenimento e, no caso carioca, ao Carnaval e, posteriormente, à música popular [...] repórter e cronistas eram treinados no dia a dia das redações para uma prática heurística e de escrita seguindo alguns procedimentos, imagens, clichês e ângulos. Desta maneira ia se construindo o perfil do jornalista especializado em cobrir determinada matéria e, no final da linha, formava o gosto e o tipo de leitor com suas expectativas (MORAES, 2019, p. 179).

Além disso, apesar de diariamente acontecerem vários crimes na capital paulista, os com assassinatos brutais e inusitados eram poucos e os jornais locais focavam mais em notícias da região, uma vez que o contato interestadual não era tão rápido e eficaz quanto 0 de hoje, devido à falta de tecnologia da época. Assim, esse é outro quesito importante para o fortalecimento do sensacionalismo na imprensa brasileira. Pois, sem ter novos crimes para noticiar, ou por não ter conhecimento de outros que aconteciam distante das metrópoles, os jornais repetiam as informações já conhecidas acerca dos casos já noticiados, dando cada vez mais ênfase a elas para tentar prender a atenção do leitor.

Durante os primeiros dias do mês, 0 Estado e 0 Correio, acompanharam de perto 0 desenrolar dos acontecimentos, veiculando as notícias de maneira recorrente, como num romance de folhetim. À falta de novidades, matérias menores requentavam as informações já conhecidas, funcionando como uma espécie de lembrete (MORAES, 2019, p. 180).

Essa prática jornalística do lembrete, mencionada pelo autor, é um característica ímpar do sensacionalismo, já que o que ele faz em seu núcleo é justamente enaltecer ao extremo um fato de 


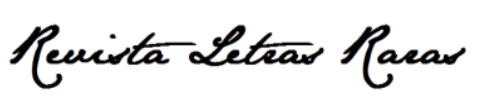

ISSN: 2317-2347 - v. 9. n. 4 (2020)

Todo o conteúdo da RLR está licenciado sob Creative Commons Atribuição 4.0 Internacional

interesse social. "Parte da população se interessava pela forma do espetáculo que o júri oferecia e, empolgada pelas notícias da imprensa, aflita em grande número às sessões (MORAES, 2019, p. 180)". O fato de 0 júri ter mudado a sua opinião após a manifestação da plateia realça o quão colocado em níveis de espetáculo o crime é. Criando uma camada de suspense, terror, investigação, mistério ao seu redor.

Tal atmosfera se mantém no livro de Fausto (2019) e deve-se, sobretudo, à colagem feita pelo autor com fotografias e recortes de jornais antigos sobre os crimes selecionados, que também remetem ao estilo vintage, uma vez que trazem o antigo ao atual. Assim, O crime da Galeria de Cristal (2019), com base da criminalidade da época, conta a história da sociedade paulistana do século XX.

Os crimes pesquisados, contados e analisados pelo autor aconteceram, respectivamente, nos anos de 1908 (O primeiro crime da mala), 1909 (O crime da Galeria de Cristal) e 1928 (O segundo crime da mala).

O primeiro apresentado no livro, ainda que não fora o primeiro a acontecer, foi "O crime da Galeria de Cristal", o assassinato de Arthur Madeiros, cometido por uma mulher com a qual ele tinha tido um envolvimento amoroso na juventude, Albertina Bonilha, e presenciado pelo atual marido dela, Eliziário Bonilha. Esse delito ficou conhecido como um "crime de honra" pela população e dividiu opiniões tanto do povo quanto da imprensa que ora defendiam a atitude de Albertina ora a acusavam. Isso porque assim que a autora do crime engravidou, na juventude, foi logo abandonada pelo pai da criança, a vítima.

Com base nesse acontecimento, árduas discussões acerca do tratamento às mulheres e seus papéis sociais foram trazidas à tona pelos jornais daquele ano e, posteriormente, retomadas pelo autor a partir da maneira pela qual a sociedade condenava a assassina muito mais por ser uma mãe solteira que levou o filho para a adoção do que por ser uma assassina.

Outro aspecto de interesse nessa história é a publicação da Revista Careta, em sua edição de 6 de março de 1909, na qual há uma foto do falecido ainda no necrotério. Novamente, o historiador faz uma referência crítica ao sensacionalismo da imprensa, que muitas vezes, para chamar mais atenção da população, mas também a fim de se sobressair à concorrência, ultrapassava os limites, ignorando os direitos humanos e o respeito às vítimas e familiares.

Não por acaso, de acordo com o autor, "O assassinato de Arthur Malheiros ganhou um rótulo de romance policial" (FAUSTO, 2019, p. 41). Tal afirmação é bastante pertinente, uma vez que no caso reconhecemos facilmente os típicos elementos de uma narrativa: narrador, personagens, enredo, tempo e espaço. E, além disso, também é fácil identificar características-chave das histórias policialescas, como vítima, suspeitos, criminosos, policiais, investigadores, detetives, júri, pistas, entre outros. 


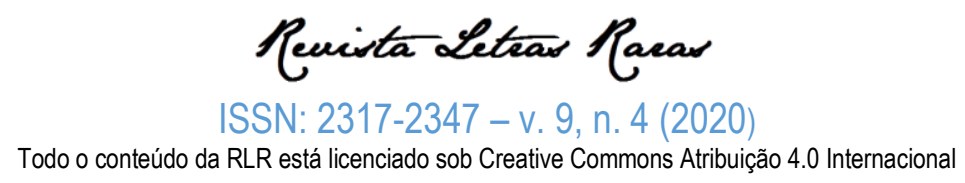

O segundo caso apresentado no livro é "O primeiro crime da mala", o qual consiste em um assassinato de um empresário pelo seu funcionário, Michel Trad. A motivação teria sido um amor secreto nutrido pelo empregado em relação à esposa de seu chefe, que não se sabe se era correspondido ou não, assim, ele tentou livrar-se do marido.

Enquanto possível história romântica, o caso servia como um espetáculo, o qual era apresentado pela imprensa em pequenos trechos, relembrando bastante aos romances publicados em folhetim. A única diferença, em síntese, é que se tratava de uma história real, na qual vítimas, envolvidos e até mesmo inocentes estavam sendo expostos. Um veículo de informação, que deveria noticiar a criminalidade de forma imparcial, neutra e séria, transforma-o em um romance, com o claro intuito de entreter e divertir, em vez de informar.

Acerca de tal caso foi produzido, inclusive, um filme. Ao analisar essa produção, bem como a recepção que teve pela a sociedade e o contexto da época, Souza (2000) discorre que: "As transgressões sociais de qualquer ordem, desde uma simples briga de rua até o crime de morte, faziam parte da sociedade urbana ou rural, sendo servidas pelos jornais diariamente aos seus leitor" (SOUZA, 2000, p. 106).

[...] chocando a elite e os estratos médios por sua violência. Seguindo o trajeto popular do caso, o imaginário sobre o crime inédito na história da cidade foi alimentado por outros meios: pelo menos um livro foi editado e uma peça teatral homônima encenada, depois de devidamente "examinada" pelos professores do Conservatório Dramático e Musical (SOUZA, 2000, p. 107).

Chocar o espectador seria, portanto, o grande intuito tanto do cinema e do teatro quanto o dos jornais, ainda que o desse último devesse ser 0 de informar.

O terceiro e último caso do livro é "O segundo crime da mala", vinte anos o separam do primeiro e, assim, na introdução dessa história, o autor dá destaque às mudanças ocorridas em São Paulo nesse espaço de tempo, contudo, algumas coisas aparentam não mudar, como a violência. Novamente, a motivação do crime é passional, dessa vez, o marido assassina a esposa após uma discussão doméstica, esquarteja-a e, pondo-a em uma mala, tenta desfazer-se do corpo.

Giuseppe Pistone, o novo assassino da mala, não despertou na população a mesma empatia que seu antecessor, Michel Trad, de início, como aponta o autor, até o momento em que começou a aluir a uma traição por parte da falecida esposa, então, muitos posicionaram-se a favor do criminoso, realçando que um adultério justificaria 0 ato.

Fausto (2019) salienta que os crimes que provocam uma divisão de opiniões tendem a ter ainda mais visibilidade. E, da mesma forma vista em 1908, o palácio onde ocorriam os julgamentos lotou-se de 


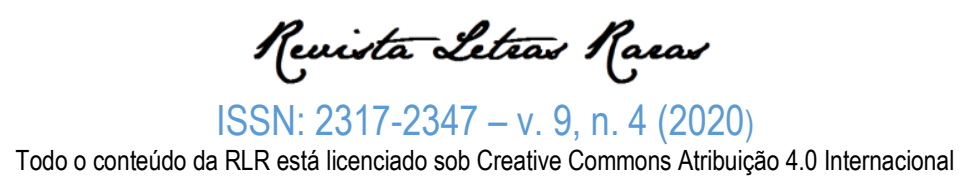

pessoas curiosas para assistir à sentença. Além da questão do feminicídio, adentrando debates acerca da violência doméstica, o autor também traz à tona outro assunto pertinente: a imigração, uma vez que tanto 0 assassino quanto a vítima, Maria Mercedes Feá, vieram da Itália para o Brasil.

Nesse caso, há várias referências ao primeiro crime da mala, como forma do autor enfatizar que o imaginário da população da época era mais duradouro se posto em contraste com o de hoje em dia em que, devido à tecnologia virtual, recebem-se várias informações instantaneamente, mas que, no entanto, não são armazenadas na memória coletiva.

Ambos os crimes, portanto, continuavam bastante vivos na lembrança popular. Entre as razões que fortalecem esse não esquecimento está o alarme feito pela mídia da época em cima dos casos. 0 que, como foi visto, apesar de ocorrer hoje em dia, não se perdura pela quantidade de informações que são lançadas ao espectador. Tanto que diversos outros crimes ocorreram em São Paulo após esses três, no entanto, não adentraram ao folclore nacional como esses.

\section{Faits Divers}

Como já foi visto, apesar de poder se sensacionalizar várias notícias, como por exemplo, as ligadas à política, Fausto (2019) pensa o sensacionalismo enquanto algo estritamente ligado a crimes. Para ele, o que realçou esse teor no contexto jornalístico foi a acolhida dos fait divers. Esse é um termo bastante utilizado pelo autor ao decorrer do livro e que pode ser relacionado com os folhetins, bastante comuns no Brasil no século XIX.

Mas 0 que se entende por faits divers, expressão traduzida literalmente para 0 português como "fatos diversos"? Em poucas palavras, o rótulo genérico refere-se a acontecimentos que ganham destaque quando se revestem de excepcionalidade, como os crimes sensacionais, os desastres de grande repercussão, os suicídios de pessoas notórias não necessariamente notáveis como senadores ou prostitutas (FAUSTO, 2019, p. 16).

Segundo o autor, os faits divers só vão ter um olhar mais atento quando Barthes analisa sua estrutura em 1960 como "[...] um relato imanente, que se fecha sobre si mesmo e não necessita de referências externas" (BARTHES apud FAUSTO, 2019, p. 16). Ou seja, algo que traz em si toda a informação que se precisa saber de maneira resumida para que o leitor compreenda de forma rápida e profícua o acontecimento.

Não obstante, "[...] a leitura de um fait divers ainda pode, cem anos depois, causar os mesmos arrepios ou espanto" (MEYER apud FAUSTO, 2019, p. 17). Isso ocorre pelo teor sensacionalista que 


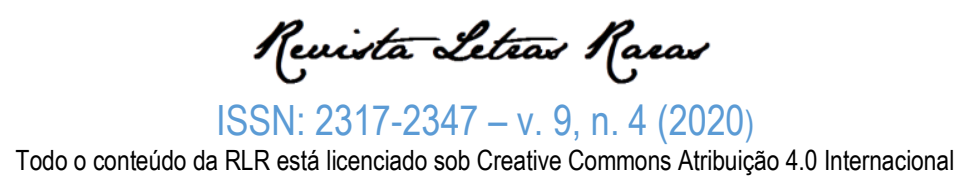

esses relatos carregam em si. Muitas vezes apelando até mesmo para o sobrenatural e exótico. Fausto (2019) sublinha tal ocorrência como uma maneira de saciar o desejo que as pessoas têm de saber da vida privada das outras detalhadamente e ainda daquilo que desconhecem em seus cotidianos. Contudo, quando eles envolvem situações mais relevantes, como é o caso da criminalidade, entram no campo da história.

Outro aspecto pertinente que realça a utilização do termo francês fait divers na imprensa brasileira é a notória referência que a França foi para Brasil do século XX. Em diferença aos dias de hoje, nos quais mídias nacionais se baseiam muito mais na cultura norte-americana. Sobretudo, no cinema, música e literatura.

Com base nisso, observamos que 0 autor perpassa constantemente por reflexões sociais e apontamentos históricos e culturais, de forma que, por meio da narrativa do crime da galeria de cristal e dos dois crimes da mala, vai contando a história de São Paulo, do Brasil, da imprensa, do jornal, da chegada do sensacionalismo em território nacional e seu desenvolvimento, bem como comparando tudo isso aos dias atuais, analisando diferenças, semelhanças, transformações. Dessa maneira, o próprio autor enfatiza como se esse procedimento acontece: "Tudo isso tendo como pano de fundo uma São Paulo hoje desaparecida, que conheci em parte, e à qual retorno sempre que possível, como homem do século XX, para quem o atual é um mundo estranho" (FAUSTO, 2019, p. 12).

Não obstante, nota-se que ao se referir à atualidade como algo de estranheza para si, o autor se aproxima do conceito de "contemporâneo", de Agamben. Para o filósofo italiano, é contemporâneo aquele que não se encaixa na época em que está sendo, portanto, inatual ao se considerar fora dela e ainda, ao se distanciar, consegue melhor enxergá-la. Dessa maneira, o autor sublinha que "[...] a contemporaneidade, portanto, é uma singular relação com o próprio tempo" (AGAMBEN, 2009, p. 57).

Boris Fausto caminha por esse trajeto ao retornar a crimes que aconteceram um século antes do seu, a fim de entender o curso da história, mas também por entender melhor aquela época do que a sua. Portanto, os aspectos vintage, com imagens em preto e branco no livro, causando certo clima nostálgico são justificados pela ausência do reconhecimento do eu na atualidade e pela presença da memória.

Nesse sentido, vê-se o apego ao jornal, a referência constante e o trabalho com ele como um aspecto imprescindível do século XX. Ainda que os jornais, tão importantes para época, encontrem-se em ruínas e esgotamento hoje, são fragmentos em que o autor se pauta para retomar a modernidade.

Os jornais mais mencionados pelo historiador ao decorrer do livro são O Estado de São Paulo, Correio Paulistano e 0 commercio de São Paulo, os quais recebem várias críticas referentes ao modo 


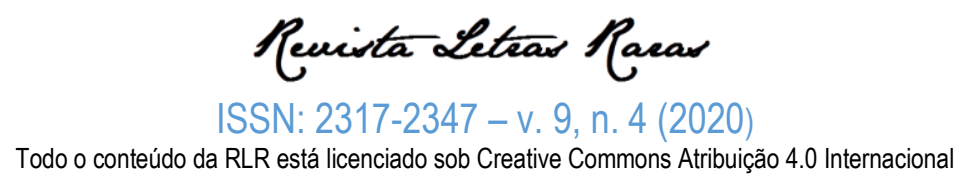

sensacionalista pelo qual retratavam e romantizavam os casos. Fausto (2019) enfatiza que os casos noticiados por tais veículos de imprensa sempre tomavam as primeiras páginas, pois o crime é interessante apenas enquanto é recente, portanto, em matéria de criminalidade, a circulação de folhetins era algo bastante recorrente, visto que era mais fáceis e rápidos de serem produzidos que os jornais.

Como já visto e apontado, a crítica social é algo muito recorrente na escrita do historiador. Seu olhar preciso perpassa pelos mais diversos contextos. Nota-se também que o autor não se prende a uma ordem cronológica dos fatos, tanto na ordem pela qual os casos estão postos no livro quanto pelos acontecimentos de cada caso.

Contundo, apesar de partir de uma escrita anacrônica, o autor tem o cuidado de ir situando o leitor ao contexto de cada história. Por exemplo, informa que "O primeiro crime da mala" e "O crime da Galeria de Cristal" estão localizados no famoso período no Brasil, de grande influência francesa, intitulado "Belle époque". Através de tais apontamentos, é pertinente realçar a maneira clara, concisa e dinâmica pela qual a sua escrita se dá.

Fausto (2019) também opta por manter a grafia antiga da língua portuguesa ao referir-se às notícias trazidas pelos jornais de 1908-1928. Tal escolha pode ser vista como um mecanismo de adentrar ao tempo em questão também pela linguagem, já que esta funciona como um elemento fundamental para entender e analisar toda e qualquer sociedade. Para melhor compreender essa questão, observemos o seguinte fragmento:

A edição de 24 de fevereiro de 1909 do jornal O Comercio de São Paulo estampou na sua primeira página um título em letras garrafais: TRAGÉDIA! Vinham depois os subtítulos: O CRIME DE HONTEM/ UM MOÇO É ATTRAHIDO AO QUARTO DE HUM HOTEL E BARBARAMENTE ASSASSINADO. O qualitativo "tragédia" se referia a um crime de grande repercussão, e a matéria, além da primeira página, ocupava ainda duas colunas da página seguinte (FAUSTO, 2019, p. 11).

Além da grafia antiga vista no jornal da época, marcada no nome do jornal, como também pelas palavras "hontem", "attrahido" e "hum", respectivamente, o advérbio "ontem", o adjetivo "atraído" e o numeral "um", também é possível notar certo teor sensacionalista, realçado, sobretudo, pelo advérbio de modo "barbaramente" e palavras escritas em letra maiúscula. Não obstante, Fausto (2019) enfatiza que é, justamente, a partir da narrativa de crimes que surge então "o relato sensacionalista" na imprensa de São Paulo.

Ao introduzir os crimes que trabalhará em seu livro, Fausto (2019) enfatiza que ambos acontecem em um: 


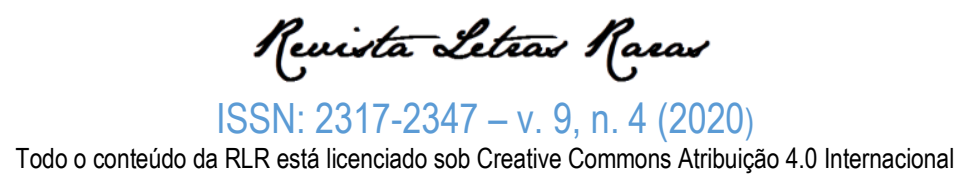

[...] período histórico que ficou conhecido por mais uma denominação francesa: a belle époque, época da mudança cultural, de invenções e inovações, vivida pelos países da Europa Ocidental entre o fim da guerra franco-prussiana de 1871 e a Primeira Guerra Mundial (FAUSTO, 2019, p. 17-18).

O historiador destaca que a expansão jornalística teve maior impulso em São Paulo, devido, sobretudo, as inovações tecnológicas que a cidade estava a par, propiciando uma circulação de informação mais rápida. Fausto (2019) ainda sublinha que o jornal era muito esperado pelas pessoas, fazendo parte de seus cotidianos, pois trazia notícias novas, mas que hoje, andamos por um caminho contrário. Para o autor "O suspense desapareceu e o jornal parece um divulgador de notícias velhas, vítima da concorrência avassaladora da mídia digital" (FAUSTO, 2019, p. 16).

O progresso, que vai transmutando a cidade colonial em centro urbano moderno, forja um signo novo para os leitores de revistas ilustradas, almanaques, álbuns comemorativos e cartões postais [...] A reprodução dos cenários citadinos, empreendida de forma canhestra, impediu que o olhar desta elite de espectadores, já acostumada à "verdade" da fotografia por dever de ofício, procedesse à mesma leitura entre um e outro artefato, entre uma e outra "reprodução" fotográfica. (SOUZA, 2000, p. 112).

A era digital, que quase aniquila a circulação de livros e jornais físicos, também atua fortemente na forma como os leitores leem. Em um tempo de muitas informações jogadas ao espectador em tempo real, tende-se a ler mais rápido e com menos atenção. Textos rebuscados ou longos são dispensados. Manchetes digitais curtas e sensacionalistas tendem a ser as mais acessadas. Assim, ainda que haja mais opções, tecnologias, inovações, mais rapidez e maior acesso à cultura, há uma clara decadência na leitura e da intelectualidade nos dias de hoje.

\section{Vestígios do romance policial}

Pode-se pensar, em um primeiro momento, que o livro de Boris Fausto (2019) se distanciaria do universo literário por trazer fatos, uma vez que a ficção é caracterizada, principalmente, pelo âmbito criativo, no entanto, é preciso lembrar que o surgimento da literatura policial se dá justamente através dos relatos jornalísticos.

A forte ligação com o contexto social sempre foi uma característica das narrativas policialescas, como muito bem observa o teórico argentino Ricardo Piglia (1986), ao destacar que por mais que o crime na sociedade sempre chamasse muita atenção, os relatos policiais dos casos eram muito rasos e se constituam em uma mera narração de fatos. Portanto, a literatura encarregou-se de fornecer detalhes mais criativos e profundos acerca dos crimes, já que as páginas noticiais não traziam. 


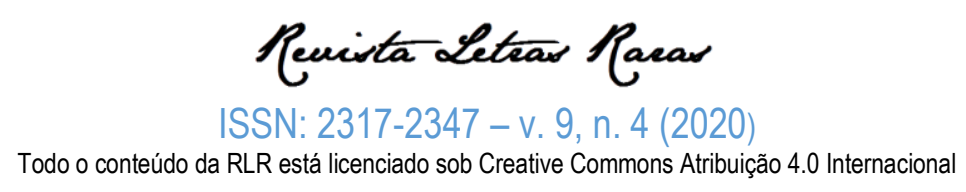

Ainda em entrevista à Folha de São Paulo, quando questionado se havia sido influenciado pelo romance policial, Boris Fausto afirma que sim, enfatizando que tanto no conteúdo quanto na forma da escrita, que é mais sucinta, marcada, sobretudo, por frases curtas e diálogos mais sintetizados.

Contudo, o autor evidencia que embora seja influenciado pela literatura não se reconhece enquanto um escritor de ficção, sublinhando que a sua técnica é pautada em aflorar a imaginação do leitor, mas acerca de casos reais. Tudo isso sob a perspectiva de uma pesquisa aprofundada, que analisa os mínimos detalhes do crime, tendo como fonte, principalmente, jornais da época em que eles foram cometidos.

Nota-se, portanto, a gama de relações que compõem a sua obra. Ora, por mais que o escritor, humildemente, rejeite a nomenclatura "criação" para seus textos, evidenciando que ele parte do real, "sem criar", é inegável que os procedimentos que administra são cabíveis aos de um multiartista.

Não obstante, vale a pena analisar a própria seleção de fragmentos a serem colados enquanto uma forma de criação. 0 gesto de mesclar a imagem ao texto pode ser visto, nessa perspectiva, como uma técnica auxiliadora do leitor para despertar, desenvolver e fortalecer uma atmosfera de investigação, suspense e mistério em seu imaginário, a qual, por sua vez, é bastante comum à literatura policial.

Assim, ao realizar a leitura de Boris Fausto (2019), também somos confundidos pela dualidade verdade-ficção, sobretudo, no que condiz a imprevisibilidade dos crimes. Em geral, principalmente na literatura policial, cada detalhe é pensado minuciosamente, pois pode ser essencial. Um mero fio de cabelo na cena inicial do crime pode ser um elemento chave para o entendimento final da trama. Contudo, a realidade não é assim tão bela. Tampouco idealizada ou criativa.

Nesse sentido, trabalhar com casos de crimes reais é lidar com uma escrita do imprevisível, já que a sua trama não é planejada, logo não obedece uma sequência lógica, um desfecho com sentido e muito menos tem uma estrutura narrativa, tal como as que conhecemos das histórias de detetive mais famosas e tradicionais, como por exemplo, as de Edgar Allan Poe, Agatha Christie e Conan Doyle.

Ao lermos o conto "Assassinatos da Rua Morgue", de Poe, publicado em 1841 e considerado o grande marco inicial da literatura policial e compararmos com os três casos selecionados no livro de Fausto (2019), vemos que há uma diferença significativa. No primeiro, o detetive é idealizado, colocado em uma posição quase que de super herói. Auguste Dupin, o primeiro detetive literário que se tem registro, tinha uma capacidade intelectual elevada, não necessitava de nenhuma ferramenta, além de seu cérebro, para resolver os casos criminais.

Por outro lado, levando em conta o contexto atual, a influência das novas tecnologias, o mundo extremamente midiático, no qual o crime vira um espetáculo, esse tipo de personagem tende a ser 


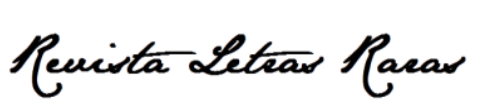

ISSN: 2317-2347 - V. 9. n. 4 (2020)

Todo o conteúdo da RLR está licenciado sob Creative Commons Atribuição 4.0 Internacional

desacreditado, muito distante do real e os escritores de literatura policial procuram cada vez mais atualizar os seus personagens. Para isso, um atalho comum à literatura detetivesca brasileira, é a inspiração em crimes reais.

Dessarte, Albuquerque sublinha que "O Brasil já tem uma literatura própria no gênero policial baseada em casos verídicos" (ALBUQUERQUE, 1979, p. 14). Segundo o autor, a histórias de detetives mais elaboradas acabam sendo direcionadas ao público adolescente, pois a grande parte dos adultos prefere casos reais ou baseados em histórias que sejam verídicas.

Não por acaso, em 2019, no mesmo ano do lançamento do livro de Boris Fausto, pela editora Companhia das Letras, foi publicado no Brasil Lady Killers: assassinas em série, de Tori Telfer, pela maior editora de terror, suspense e policial no país, DarkSide Books. Nesse livro há uma seleção de quatorze histórias de mulheres que cometeram crimes extremamente cruéis, ao redor do mundo, em diferentes épocas.

Assim como Boris Fausto, Tori Telfer também se baseia em fatos para escrever, partindo de longas pesquisas históricas e jornalísticas, que ecoam em textos bem detalhados, que contam os crimes de forma crítica, reflexiva e ainda assim, literária. Ambos se aproximam muito do gênero contos, tanto pelo aspecto ficcional quanto pela extensão da redação. Contudo, é interessante realçar que eles "se aproximam", não se limitam a essa categorização, justamente, devido a hibridez de seus livros.

No entanto, quinze anos antes, mais precisamente no ano de 2004, o também paulista, Valêncio Xavier, já trabalhava com essa técnica do recorte de casos de crimes reais do jornal e de colagem em livros. Pode-se considerar Xavier como um multiartista totalmente embebedado pelo diálogo midiático em torno do crime. Não obstante, além de escritor, ele também foi cineasta, jornalista e apresentador de TV.

Em Crimes à moda antiga (2004), Valêncio Xavier seleciona oito casos de criminalidade reais, que aconteceram em meados do século XX no Brasil. Por coincidência, ou não, entre esses estão os três crimes que Boris Fausto (2019) selecionou para o seu livro. Contudo, a maneira pela qual Xavier (2004) escreve, ou reescreve, tais histórias, é muito mais ficcionalizada. Diferente de Fausto, o autor não busca estabelecer um compromisso imparcial com a realidade ainda que logo na capa de seu livro, abaixo do título Crimes à moda antiga, haja uma espécie de subtítulo: Contos Verdade.

A partir disso, vê-se que o autor tem ciência de que perambula na fronteira entre ficção-realidade, pois se trata de uma sentença peculiar e contraditória. Se são "contos", fazem parte do campo da ficção. Ora, como usar a palavra "verdade"? Por outro lado, tratam-se de crimes que realmente aconteceram. Eis a confusão. Pois bem, diante disso, pode-se aludir ainda ao conceito de intermídia, que propõe uma 


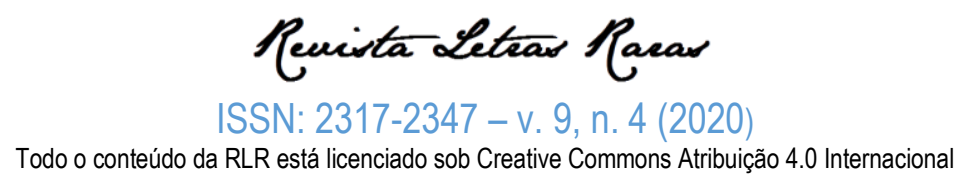

reflexão semelhante, sob uma gama de possibilidades, de nomenclaturas, de classificações e categorizações, ele caminha por meio de travessias e intersecções, sendo difícil dizer a qual mídia a obra pertence mais.

Valêncio Xavier também possui outro livro bastante pertinente no que condiz à ruptura da estrutura e o diálogo de diversas áreas, trata-se de 0 mez da grippe, publicado pela primeira vez em 1981, que traz três planos: no primeiro, retrata o contexto da capital paranaense, Curitiba, durante a gripe espanhola; no segundo, apresenta a narrativa de uma moradora local, Dona Lúcia, da qual o leitor fica por desconhecer a informação se é uma personagem ou se existiu de fato; e em terceiro lugar, o fim da primeira guerra mundial. Tudo isso a partir de vários recortes de jornais, a mídia principal que embasa seus livros e também os de Fausto e Telfer (2019).

Ainda, é pertinente destacar que desde o início a literatura detetivesca nacional é perpassada por mídias, não é algo novo, mas sim que teve mais ênfase recentemente devido à tecnologia. Tanto que, de acordo com Reimão (2005), a primeira narrativa policial brasileira, O mistério, de quatro escritores: Coelho Neto, Afrânio Peixoto, Medeiros e Albuquerque e Viriato Corrêa, foi publicada inicialmente em um jornal. Segundo a autora, $A$ folha publicou o romance em capítulos, no ano de 1920.

Assim, é relevante também trazer à tona a famosa afirmação de Álvaro Lins, um dos grandes nomes do romance policial brasileiro: "A ficção do romance policial e a ficção do romance literário são realidades diversas" (LINS apud PONTES, 2007, p. 5). Com isso, entende-se que é incabível julgar um com todos os critérios que se avalia o outro. Podemos compará-los, é claro, mas entendendo o espaço de cada um.

Dias (2016) ao comentar sobre a escrita fragmentária valenciana faz alusão a uma colcha de retalhos. Para a autora, a partir de uma camada onírica afinada ao lado cineasta de Valêncio Xavier ele constrói uma escrita feita de detalhes, ao passo que também é minimalista e ainda ressoa poesia. Essa mistura, para ela, remete ao sonho, ao mistério.

A pesquisadora também dá ênfase ao trabalho de Valêncio Xavier à moda barthesiana, enquanto um "tecido de citações" (BARTHES apud DIAS, 2016, p. 33), pelo qual "o escritor é um colecionador de relíquias e restos" (DIAS, 2016, p. 33). Isto é, ele está nos dois extremos, entendendo a oposição de relíquias e resto enquanto o máximo e mínimo. Ainda nesse contexto do escritor enquanto um colecionador e um acumulador, percebe-se que a autora revisita suas ideias acerca de Valêncio Xavier e uma suposta estética de almanaque. Boris Fausto também pode ser visto da mesma maneira. Não apenas por trabalhar com os casos já trabalhados por Xavier (2004), mas também e, principalmente, por utilizar a técnica do recorte e da colagem de fragmentos de diversas origens. 


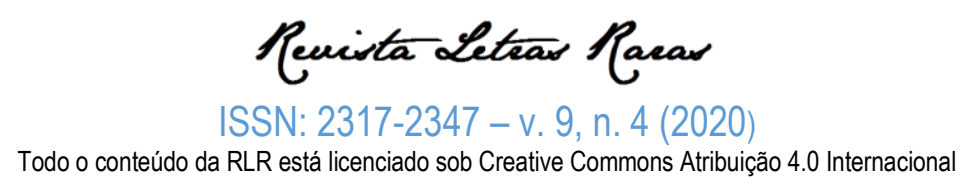

Em geral, os crimes sensacionais tomam grandes proporções, portanto, sendo natural essa abrangência em diversas mídias. Contudo, o que é diferente na escrita de Fausto (2019) e Xavier (2004) é a forma como tentam capturar os fragmentos sobre determinado crime de todas as mídias que tais casos adentram.

Nesse contexto, é pertinente a afirmação de Pontes (2007), ao escrever sobre a literatura policial brasileira, dando ênfase ao autor Rubem Fonseca: "Ele é um escritor de vários temas e muitos assuntos, de algumas formas e muitas medidas. E é também um escritor inquieto e mutante" (PONTES, 2007, p. 162). O termo "mutante" é bastante conveniente para um escritor de literatura policial brasileira, talvez 0 mais apropriado. Isso em razão dos diversos exemplos que reafirmam a hibridez tanto na escrita quanto na carreira dos autores. Observando, mais uma vez, que Fausto é historiador, professor e escritor e Xavier foi cineasta, jornalista, escritor, roteirista e diretor de TV.

Pontes (2007) ainda salienta que, em seu ponto de vista, Rubem Fonseca teria sido o maior autor do país no gênero policial. Muito embora essa afirmação seja interessante, uma vez que a importância da produção de Rubem Fonseca no gênero é indiscutível, ela talvez possa ser mais discutida hoje em dia, devido ao grande legado construído por Luiz Alfredo Garcia-Roza.

Outro autor brasileiro de grande destaque no cenário da literatura policial é Raphael Montes e que também vem trabalhando com a mesma técnica já utilizada por Valêncio Xavier e Boris Fausto de se basear em crimes reais para escrever suas narrativas ficcionais. Além da literatura, o escritor também vem trabalhando com roteiros de filmes, com os mais recentes "A menina que matou os pais" (2020) e "O menino que matou os meus pais" (2020), ambos baseados no caso criminal que teve o maior alcance midiático no país nos últimos tempo: o assassinato do casal Von Richthofen, por sua filha, Suzane Von Richthofen. Mais uma vez, observa-se o quanto a relação midiática se fortalece ao redor dos crimes, sobretudo no diálogo entre literatura e cinema.

Não obstante, Brait (2010) sublinha tais intersecções da literatura com outras linguagens evidenciando o cruzamento, desdobramento e a multiplicidade de vozes que ecoam disso. Para a autora, os textos atuais estão repletos de links que ligam a outros textos, formando uma enorme rede de conexões. Dessa forma, vê-se que essa é uma forma mais modernizada e tecnológica de se pensar a colagem e montagem. Portanto, a construção de sentido a partir de uma leitura é cada vez mais heterogênea e o texto fechado em si mesmo torna-se uma possibilidade improvável.

Nesse contexto, vale a pena refletir sobre o que Higgins (2012) realça acerca dessa heterogeneidade: "Na intermídia, por outro lado, o elemento visual (pintura) se funde conceitualmente com as palavras" (HIGGINS, 2012, p. 48). Ou seja, na obra intermidiática a fusão entre imagem e texto 


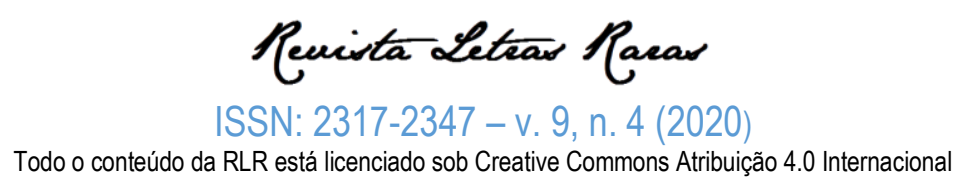

é elementar. Além disso, o autor ainda menciona que essa mistura foi vista com ênfase na poesia concreta, onde tanto 0 aspecto visual quanto o conteúdo eram fortemente seguidos. mas também está cada vez mais comum nos depararmos com romances visuais e, futuramente, outras produções semelhantes tendem a vir.

Segundo Higgins (2012), nada parará a inovação. Há sempre alguém, em algum lugar, na vanguarda, pensando em algo diferente do que vem sendo efeito.

\section{Considerações finais}

Com base no que foi apontado e analisado ao decorrer dessa pesquisa, observou-se que 0 crime da Galeria de Cristal: e os dois crimes da mala São Paulo, 1908-1928 (2019) é um livro muito bem elaborado, construído a partir do processo intermidiático de recorte e colagem de fragmentos de diversas naturezas. Assim, a partir de sua leitura, notamos referências das esferas historiográfica, jornalística, literária, cinematográfica e artística, tudo isso, sob o olhar de um historiador, mas também de um autor influenciado pelos romances policiais, formando, portanto, o que podemos chamar de uma "abordagem e uma leitura multimídia" da criminalidade e da sociedade moderna do século XX.

Essa mescla é realizada de forma que nenhum meio se sobreponha ao outro. Ambos dialogam, se conectam e geram significado através do fio criminalístico. A atração que a sociedade possui por temas relacionados a assassinatos, crimes e criminosos é manifestada de maneira profícua nos casos selecionados por Fausto (2019), evidenciando o porquê do sensacionalismo funcionar muito bem no Brasil.

Dessa maneira, tendo em vista a sociedade que consome em grandes quantidades produções sobre crimes, das mais diversas mídias, a literatura policial nacional tende cada vez mais a funcionar de forma antropofágica, como é feito nesse livro. Recontando casos de maneira mais detalhada e recorrendo a diversas fontes para isso. Além do mais, o leitor também assume um novo papel. $A$ narrativa-montagem exige um espectador-detetive. Aquele que deve ser mais atento, crítico, preenchendo as lacunas e investigando as entrelinhas.

Portanto, a fragmentação e indefinição do gênero textual e a multiplicidade das linguagens e imagens são traços da modernidade que se expandem à contemporaneidade e acabam ecoando na literatura. A colagem, que teve ênfase no cubismo e dadaísmo, deixa de ser um experimentalismo artístico e passa a ser central nas produções atuais. 


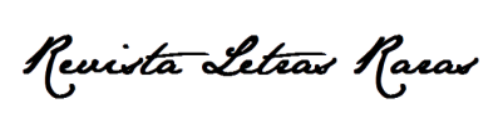

ISSN: 2317-2347 - v. 9, n. 4 (2020)

Todo o conteúdo da RLR está licenciado sob Creative Commons Atribuição 4.0 Internacional

A partir da técnica ready-made, ele evoca a memória jornalística e a folclórica, mas no campo da ficção. A descontinuidade nesse processo consiste na substituição de uma retomada linear da memória e da história pelo recorte apenas de fragmentos delas. Os novos modos de se conceber escrita, som e imagem são perpassados pela tecnologia e pelo prefixo "inter". Segundo Antelo (2000) o readymade, está interligado à estética dadaísta, que representa em seu núcleo a agonia da sociedade, possuiu, de um lado, ares de fins, sobretudo, ao romper com a arte tradicional, no que condiz ao conceito de belo e, por outro lado, traz ares de começos, principalmente, por proporcionar novos olhares e significações para o comum, o qual passa a ser o centro desse novo conceito de arte.

\section{Referências}

AGAMBEN, Giorgio. O que é o contemporâneo? In: O que é o Contemporâneo? e outros ensaios. Trad. Vinícius Nicastro Honesko. Chapecó: Argos, 2009.

ALBUQUERQUE, Paulo de Medeiros e. 0 mundo emocionante do romance policial. Rio de Janeiro: Francisco Alves, 1979.

ANTELO, Raúl. Territorial Signs as Ready-mades. In: GRANDIS Rita de ; BERND, Zilà. (Org.). Critical Studies: Unforeseeable Americas: Questioning cultural hibridity in the Americas. Amsterdam: Rodopi, 2000.

BRAIT, Beth. Literatura e outras linguagens. São Paulo: Editora Contexto, 2010.

DIAS, Ângela Maria. Valêncio Xavier o minotauro multimídia. Rio de Janeiro: Oficina, 2016.

FAUSTO, Boris. O crime da galeria de cristal: e os dois crimes da mala São Paulo 1908-1928. São Paulo: Companhia das Letras, 2019.

FERREIRA, Glória. Escritos dos Artistas Anos 60/70. Rio de Janeiro: Jorge Zahar, 2006.

HIGGINS, Dick. Intermedia. In: HIGGINS, Dick. Horizons. New York: Ubu editions, 2007.

HIGGINS, Dick. Intermídia. Trad. Amir Brito. In: VIEIRA, André Soares; DINIZ, Thaïs Flores Nogueira (Org.). Intermidialidade e Estudos Interartes - Desafios da arte contemporânea, v.2. Belo Horizonte: Rona Editora FALE/UFMG, 2012.

LONGHI, Raquel Ritte. Intermedia, ou Para entender as Poéticas Digitais. In: INTERCOM - Sociedade Brasileira de Estudos Interdisciplinares da Comunicação XXV Congresso Brasileiro de Ciências da Comunicação - Salvador/BA - 1 a 5 Set 2002. Disponível em: http://www.por tcom.intercom.org.br/pdfs/133855906519997470982936078959703706716.pdf. Acesso em: 22 abr. 2020.

SOUZA, José Inacio de Melo. As imperfeições do crime da mala. Revista USP. São Paulo: USP 2000.

MORAES, José Geraldo Vinci de. A trilha sonora de um crime (1905). Revista do Centro de Pesquisa e Formação. São Paulo: SESC, 2019.

PIGLIA, Ricardo. Sobre el género policial. In: Crítica y ficción. Buenos Aires: Lectulandia, 1986.

PONTES, Mário. Elementares notas sobre a história da literatura policial. Rio de Janeiro: Odisseia, 2007. 
REIMÃO, Sandra. Literatura policial brasileira. Rio de Janeiro: Jorge Zahar, 2005.

TELFER, Tori. Lady Killers: assassinas em série. São Paulo: Darkside Books, 2019.

XAVIER, Valêncio. Crimes à moda antiga. São Paulo: Publifolha, 2004.

XAVIER, Valêncio. 0 mez da grippe e outros livros. São Paulo: Companhia das Letras, 1998. 